Kaygl, 20(I)/2021: 212-238. Araştırma Makalesi | Research Article

Makale Geliş | Received: 08.10.2020

Makale Kabul | Accepted: 25.12.2020

Yayın Tarihi | Publication Date: 15.03.2021

DOI: $10.20981 /$ kaygi.889659

\title{
Mücella CAN
}

Dr. Öğr. Üyesi | Assist. Prof. Dr. Atatürk Üniversitesi, Edebiyat Fakültesi, Felsefe Bölümü, Erzurum, TR Atatürk University, Faculty of Letters, Department of Philosophy, Erzurum, TR

ORCID: 0000-0002-3987-2805 mccan@atauni.edu.tr

\section{İktidarın Kaynağı, Araçları ve Yozlaştırıcı Etkisi}

\section{$\ddot{O} \mathbf{z}$}

Bu çalışmada iktidar kavramı ele alınıp incelenmektedir. Öncelikle, iktidarın tarihi kısaca izah edilmektedir. İktidarın ne olduğu ortaya konulduktan sonra iktidarın kaynağı ve araçları hakkında bilgi verilmektedir. Ayrıca iktidarın yozlaştırıcı etkisi de çalışmanın kapsamı içerisindedir. Kişilik, mülkiyet ve örgüt iktidarın kaynakları olarak değerlendirilmektedir. İktidarın araçları ise caydırma, ödüllendirme ve ikna etme-koşullandırma şeklinde verilmektedir. İktidar bir insani deneyimdir. İnsanlar arasındaki ilișkilere bağlı olarak ortaya çıkan iktidar hayatın her alanında vardır. Evrensel bir deneyim olması nedeniyle her insan bir şekilde iktidarı kullanmıștır. Hepimiz, çok sayıda iktidar yapılarıyla karşı karşıya bulunmaktayız. Bu iktidar yapılarının birçoğu günlük hayatın normal yönleridir. Örgütlenmiş bir toplulukta yaşayan her insan, hayatını bir dizi iktidar yapısı arasında geçirir. İktidar insan hayatının her aşamasında bulunmaktadır. İnsanların bir arada yaşadıkları her yerde iktidar vardır ve iktidar insanlar arasındaki ilişkilere bağlı olarak kendiliğinden ortaya çıkmaktadır.

Anahtar Kelimeler: İktidar, Kişilik, Mülkiyet, Örgüt, Yozlaşma.

\section{The Source, Tools and Corrupt Effects of Power}

\begin{abstract}
In this study, the concept of power is handled and analyzed. First of all, the history of power is explained briefly. After revealing what power is, information about the source and tools of power is given. In addition, the degenerating effect of the power is also within the scope of the study. Personality, property and organization are considered as sources of power. The tools of power are given as deterrence, rewarding and persuasion-conditioning. Power is a human experience. The power that emerges due to the relations between people is present in all areas of life. Because it is a universal experience, every human being has exercised power in some way. We are all confronted with a multitude of power structures. Many of these power structures are normal aspects of daily life. Every person living in an organized community spends his life among a series of power structures. Power exists at every stage of human life. Wherever people live together, there is power and power arises spontaneously depending on the relationships between people.
\end{abstract}

Keywords: Power, Personality, Property, Organization, Corruption. 


\section{Giriş}

Yunan mitolojisindeki ilk şairlerden Hesiodos, Teogoni'de insanların günlük işlerinden iktidarın nasıl ortaya çıktığını güzel bir şekilde yorumlar. Hesiodos’un mitleri, anlamsız bir kaostan çıkan iktidarın, anarşi ve kargaşanın anti-tezi halini almasının şairane bir üslupla hikâye edilişidir. Zeus'un Titanlarla yaptığı savaş tamamen bunu göstermektedir. Zeus, iyilik ve kötülükleriyle iktidarı kişiliğinde somut hale getirmiştir. İktidarı olup bitenlerin ve bundan böyle düzenin bir ölçüde tahmin ve kontrolü uğrunda kullandığından, kendisini yüce bir konuma yerleştirmiştir. Zeus, kaosu dizginleyip kontrol altında tutabilmiş ama onu bütünüyle yok edemediği için tekrar başkaldırmasını da önleyememiştir. Günümüzde olduğu gibi o dönemde de kaba ve dehşetli bir şekilde ortaya çıkmış olsa da iktidar, kaosa tercih ediliyordu. İktidarın kaosa tercih edilmesinde düşünce ve akıl en önemli görevi üstlendiği gibi her şeye rağmen iktidara meydan okuma işlevini de yerine getiriyordu. Çünkü düşünce ve aklı bütünüyle kontrol altına alıp yok etmek mümkün değildir. İktidarın, düşünce, akı1 ve bilgi olmaksızın varlığını devam ettirmesi imkânsız denecek derecede zordur. Düşünce, akıl ve bilginin ürünlerini kendisi için araçlar olarak kullanan iktidar, onların her an kendisine karşı koymak isteyeceklerini de göz önünde bulundurmak zorundadır (Berle 1980: 13-14).

Onu elinde bulunduranların uyguladığ ş̧ekli ile iktidarın yazılı tarih ile başlayan bir gerçek olduğu söylenebilir. Hayvanlar arasında bile örgütlenmiş bir güç kullanımından söz edenler, iktidarın insanlardan önce var olduğunu dile getirmektedirler. Mağara hayatı yaşayan insanların tarihi üzerine yapılan çalışmalardan hareketle, mağaraların içerisindeki resimlerde, avcıların, güçlü ve çevik hayvanları, aralarından birinin onu öldüreceği ana kadar yordukları görülmektedir. Bu tür bir örgütlenme, bir plan hazırlayabilecek, emirler verebilecek, bu emirlerin yerine getirilmesini sağlayabilecek ve muhtemelen, öldürülen hayvanı grup arasında bölüştürecek bir lideri gerektirir. Bir liderin, kabile reisinin veya kralın elindeki iktidarın örneklerine en eski arkeolojik kazılarda da rastlanmaktadır. Bir din adamının, 
şamanın ve toplum içerisinde bilgece hareket eden bir kişinin temsil ettiği düşünce sisteminin de iktidarı elinde tutanlarla birlikte var olduğu ve varlığını devam ettirdiği tarihsel olgular arasındadır. İktidar bu anlamda her zaman dinsel özellik taşıyan otorite veya güçlerle bağlantı içerisinde olmuştur. Hatta arkaik ya da değil toplumsal ve siyasal hiçbir iktidar yapısı aşkın bir odağa gönderme yapmadan varlığını sürdüremez (Akal 1998: 105).

İktidar, insanın bir özelliğidir. İktidar, ona sahip olan biri olduğu zaman vardır. İktidara ulaşma arzusu her insanda bulunur. Evrensel bir insan deneyimi olduğu için hayatlarının herhangi bir döneminde küçük çaplı da olsa elinde iktidar bulundurmayan ve onu kullanmayan hiç kimse yoktur. Bir annenin çocukları üzerinde, bir babanın ailesi üzerinde, yaşlı bir insanın kendinden genç olanlar üzerinde belli bir iktidarından söz edilebilir. Hepimiz, çok sayıda iktidar yapılarıyla karşı karşıya bulunmaktayız. Bu iktidar yapılarının birçoğu günlük hayatın normal yönleridir: Kalabalık bir kavşaktaki polis memuru, bir mükellefin vergisi üzerinde duran maliye görevlisi, bir şehir planlama müdürü, bir şirketin ya da içerisinde yer aldığımız herhangi bir kurumun yöneticisi vb. Örgütlenmiş bir toplulukta yaşayan her insan, hayatını bir dizi iktidar yapısı arasında geçirir. İktidar aslında insan hayatının her aşamasında bulunmaktadır. İnsanların bir arada yaşadıkları her yerde iktidar vardır ve iktidar, insanlar arasındaki ilişkilere bağlı olarak kendiliğinden ortaya çıkmaktadır (Berle 1980: 32).

\section{Bir İnsan Deneyimi Olarak İktidar}

Sahip olma, denetim altında tutma, yönlendirme, hizaya getirme, kontrol edebilme, bir şeyi yapabilme kapasitesi ya da gücü anlamlarına gelen iktidar, toplumsal yaşamın temel ve kaçınılmaz bir boyutudur (Sinclair 2000: 1215). 'Bir iradenin, sosyal ilişkiler çerçevesi içerisinde ona karşı gelinmesi durumunda bile uygulanabilmesi olanağı' (Weber 1962: 117) şeklinde tanımlanabilecek olan iktidar, yalnızca kuramsal olarak düşünülüp değerlendirilebilecek bir sorun olmayıp aynı zamanda insanların deneyimlerinin de bir parçasıdır. 'Kendi iradesiyle, diğer insanların davranışlarını belirleme yetisi' olarak da tanımlanan iktidar sayesinde bazı insanlar, başka insanlara 
kendi iradelerini ve amaçlarını empoze etmeye çalışırlar. Bu şekilde bir irade dayatma ve onun belirlediği hedefe ulaşma kapasitesi ne denli büyük olursa iktidar da o denli büyük olur (Galbraith 2004: 12). Temeli, insanın tutma ve koruma güdülerine kadar geri götürülebilecek olan iktidara yalnızca devletin sahip olduğunu söylemek doğru değildir. İktidara her birey ve herhangi bir biçimde birlik olarak örgütlenmiş her grup sahiptir. Aslında iktidara sahip olma arzusunun insanın doğasında olduğu söylenebilir. Russel'in ifadesiyle, insanın sonsuz arzuları arasında en güçlü olanlar, iktidar ve ihtişam arzusudur (Russel 2003: 11). Bu iki arzu birbiriyle yakınlık gösterse de aynı şey değillerdir. Ancak ihtişam ve şöhret sahibi olmanın da çoğunlukla iktidar sahibi olmaya bağlı olduğu söylenebilir. Diğer taraftan ihtişam ve şöhret sahibi olan insanların her zaman olmasa da çoğunlukla iktidarı ellerine alabilecek bir güçlerinin olduğu da göz ard1 edilmemelidir.

Taraflar arasındaki ilişkilere göndermede bulunan iktidar ilişkileri, rızaya veya şiddete dayalı ilişkilerden farklıdır ve kendi başına bir durum olarak alınmayıp bir ilişki şeklinde değerlendirilmelidir. Çünkü o bir işleyiş halinde ortaya çıkmaktadır. Ancak iktidarın işleyişi bireysel ya da kolektif yalnızca taraflar arasındaki bir ilişki değildir; iktidarın işleyişi bazılarının başkaları üzerindeki eylem kipidir. Bu demektir ki yalnızca birilerinin başkalarına uyguladığı iktidar vardır. Yani iktidar bir etkinlikte bir eylemde ortaya çıkmaktadır. Bir başka ifadeyle iktidar, başkalarının eylemlerinin değiştirilmesi ve manipüle edilmesine yönelik bir iradedir. İktidar sahibi olan kişi ya da kişiler ya başkaları için belirledikleri bir eylem biçimini onlara dayatmakta veya başkalarının eylem olanakları arasından kendi iktidarları için uygun düşecek olan bir eylem olanağına onları yönlendirmeye çalışmakta ya da onların söz konusu eylem olanağını tercih etmelerine zemin hazırlamaya uğraşmaktadırlar. İktidar ilişkisinde başkalarının eylemlerinin değiştirilmesi amaçlansa da bir iktidar ilişkisini tanımlayan, doğrudan ve aracısız olarak başkaları üzerinde değil; başkalarının eylemleri üzerinde eylemde bulunan bir eylem kipi olmasıdır (Foucault 2000: 72-73). İktidar tam anlamıyla gerçekte şeyler üzerinde bir güç sorunu olarak değil, başkaları üzerinde, başkalarının eylemleri üzerinde bir egemenlik sorunu olarak ortaya çıkar. İktidar fiziksel şiddet biçiminde 
bedenlerimize değil eylemlerimize etkide bulunur ve yalnızca özgür öznelere özgür oldukları sürece uygulanır (Merguior 1986: 145).

Başkalarının eylemlerini etkileyebilme, kontrol edebilme olanağı olması dolayısıyla iktidar ilişkisinde her zaman ötekinin bir tür tahakküm altına alınması söz konusudur. Tahakkümde ise yapmalısın/yapmamalısın şeklinde dile getirilebilecek olan emretme/yasaklama durumu söz konusudur. Ancak bu ilişki hükmeden-hükmedilen halini aldığı zaman kurallı bir ilişki bile olsa her iki tarafta bulunanların doğal hallerinden uzaklaşma ihtimali vardır. Doğal olan durum ve ortamdan uzaklaşmak ise yozlaşmaya bir başlangıç oluşturmaktadır. İktidara sahip olanlarda ve ona maruz kalanlarda meydana gelecek olan yozlaşma, iktidarın ortaya çıkmasına neden olan kaynaklar ve iktidarın uygulanmasında müracaat edilen araçlardan bağımsız olarak ele alınamaz. İktidar kendi başına bir şey olarak düşünülemeyeceği için onun ortaya çıkmasına neden olan kaynaklar ve ona uygulanma olanağı veren araçların zaman içerisinde geçirmiş olduğu değişim ve dönüşümler iktidar ilişkilerinin de değişim ve dönüşümüne neden olurlar. Başkalarının eylemlerinin yönlendirilmesi ve değiştirilmesine yönelik olan iktidar ilişkisinin işleyişini sağlayacak araçlar ve iktidar ilişkilerini uygulayanlara uygulama yetkisini veren kaynaklar iktidarın ontolojik ve epistemolojik temellerini oluşturmaktadır. $\mathrm{Bu}$ nedenle epistemolojik anlamda iktidarla bilgiyi birbirinden ayırma olanağı yoktur. İktidar ilişkisi, bilgi alanının karşılıklı bağlantılı yapısına dayanır. Bilen özne ve bilinen bütün nesneler, birbiriyle içiçelik arz eden bilgi ve iktidarın temel alanlarının, tarihsel dönüşümlerinin etkisi olarak düşünülmelidir (Foucault 1991: 27-28).

\section{İktidarın Kaynakları ve Araçları}

Hangi tür iktidar olursa olsun onu kendisini ortaya çıkaracak olan iktidar ilişkisinin işleyişini sağlayan araçlar ve sözü edilen iktidar ilişkilerine bağlı olarak ortaya çıkan iktidarı uygulama yetkisi veren kaynaklardan bağımsız düşünme olanağı yoktur. İktidarın kaynakları kişilik, mülkiyet ve örgütlenmedir (Galbraith 2004: 15). İktidarın bu kaynakları karşısında, onlarla değişik şekillerde kombinezonlar oluşturacak 
olan çeşitli araçlardan söz edilebilir. $\mathrm{Bu}$ araçlar aracılı̆̆ıyla iktidar sahiplerinin iktidarlarını devam ettirmeleri sağlanmaktadır. İktidarın uygulanmasında kendilerine müracaat edilen araçlar ise caydırma, ödüllendirme ve ikna etmedir. Kaynaklar ve araçlar arasında oluşacak olan basit bir ilişkiye göre kişilik, genellikle zor kullanma ve caydırma araçlarını tercih etmektedir. Bir başka anlatımla caydırıcı bir güce sahip olma genellikle kişiliğin kendisine müracaat ettiği araçların başında gelir. Mülkiyet ödüllendirmeyi örgüt ise çoğunlukla ikna etme yolunu tercih eder. Kişi ya da kişilerin eylemlerini değiştirmenin yolu ya onlara karşı zor kullanma-caydırma, ödüllendirme ya da onları ikna etmedir. İktidarın araç ve kaynakları, iktidara sahip olan kişi ya da kişilerin elinde zaman ve mekâna göre değişik biçimlerde ortaya çıksa da özleri itibariyle herhangi bir farklılıktan söz etmek zordur. Hemen hemen her iktidarın kendilerine az ya da çok başvurabileceği bu araç ve kaynaklar her bağlamda bir etkileyen ve etkilenen ilişkisini ortaya koymaktadırlar. $\mathrm{Bu}$ nedenle iktidardan söz edildiği zaman, kendisini iktidar olarak somutlaştıran bir iradenin gücünü başkalarına nasıl kabul ettireceği ve başkalarının rızasını nasıl elde edeceği sorunundan söz ediliyor demektir. İktidar denen somut iradenin kendisini başkalarına kabul ettirmesi, iktidarın meşruiyeti yani başkalarının rızasıyla doğrudan bağlantılıdır. İktidarın kullanımıyla ilişkili bu durum, onun toplumsal, siyasal ve ahlaki olarak haklı kılınmasını gerektirir. Çünkü iktidar kullanımı çok kere bazı kişilerin çıkarlarının başkaları tarafından engellenmesi şeklinde karşımıza çıkmaktadır (Barry 2003: 98). Bu nedenle iktidarın kullanımı, aynı zamanda onu kullananlara birtakım sorumluluklar da yükler. 'A'nın B üzerinde iktidar sahibi olduğunu ifade etmekle, A'nın B'nin eyleminden veya durumundan bir dereceye kadar haklı olarak sorumlu tutulabileceği sonucuna ulaşmak arasında özel olarak yakın bir ilişki bulunmaktadır.' (Connolly 1983: 95). Bu tür yaklaşımlarda iktidar, bir şeye iktidar anlamında olmaktan çok hemen hemen her zaman bir şeyin üzerinde iktidar anlamında yorumlanır. Buradaki bir şeyden kasıt, iktidarın bir ilişki şeklinde ortaya çıkmasından dolayı, başkalarının iktidarın etkisine maruz kalan eylemleridir. Başkalarının eylemlerini değiştirmeye yönelik bir güç olarak ortaya çıkan iktidar, caydırma, ödüllendirme ve ikna araçlarına başvurur. İktidarın kullanımı için 
gerekli olan bu her üç araç aynı zamanda iktidarın bu adlarla anılmasına da neden olmaktadır.

Zor ya da caydırıcı bir güç aracılı̆̆ıyla ortaya konulmaya çalışılan iktidar zorlayıcı ya da caydırıcı iktidar olarak nitelendirilmektedir. Caydırıcı iktidar, kendisi için nesne alanı olarak belirlediği kişi ya da kişilerin tercihlerinden vazgeçmelerini sağlayacak kadar can sıkıntısı ve acı vaat eden bir gerçekleştirme koşulu ileri sürerek bireyin ya da birey gruplarının kararlarını belirleme gücüne sahiptir. Bu güç sayesinde kendisi için nesne alanı olarak düşündüğü her şeyi kendine boyun eğdirmeğe çalışır. Caydırıcı iktidar her zaman hedef nesne olarak belirlediği eylemlerin değiştirilmesi ve onların yerine kendisinin kabul edebileceği yeni birtakım eylem biçimlerini yerleştirmeyi amaçlamaktadır (Galbraith 2004: 14,23). Zor ya da şiddete maruz kalan insanın gerçekleştirmeyi düşündüğü eylem ya da eylemlerini değiştirme ihtimali her zaman vardır. Hatta kişilerin eylemlerini değiştirmesi için koşulların çok da acımasız olması gerekmez. Caydırıcı iktidar, her ne kadar zora ya da şiddete başvurarak kişilerin eylemlerini değiştirmeyi hedeflese de söz konusu iktidarın nesne alanı olarak belirlediği insanların içerisinde bulundukları toplumsal, siyasal ve psikolojik koşullar oldukça önemlidir. Çünkü insanların içerisinde bulundukları koşullar, onların eylemlerinin değiştirilmesini kolaylaştırıcı ya da zorlaştırıcı bir zemin durumundadır. Örneğin, iktidarın nesne alanını oluşturan insanların siyasal ve psikolojik açıdan içerisinde bulundukları korku atmosferi, onların eylemlerinin değiştirilip yönlendirilmesine çoğunlukla kolaylaştırıcı etkide bulunur. Hatta siyasal iktidarların insanların düşünüş ve davranış tarzlarını değiştirmeye çalışmaları ve bu çabalarında başarılı olmaları, egemen oldukları toplumlarda yaydıkları korku havası ve eleştirel yeteneğin gelişmesini engelleyen araçlara sahip olmalarına bağlıdır (Tormey 1992: 38). Siyasal iktidarların yaydığı korku havası, iktidarın etki alanında bulunan insanlarda kendilerine uygulanacak zor ya da fiziksel güç kaygısı yaratmaktadır. Çünkü toplumsal düzeni sürdüren ve kendini yeniden üreten her iktidar yıkıcılık özelliğini içeren şiddet öğesine sahiptir. Bu nedenle iktidar kendi başına var olamaz ve kendini yeniden üretme gücünün yanısıra kendini ortadan kaldırabilme yetisine de sahiptir (Riches 1989: 73). 
Caydırıcı iktidar çoğunlukla maddi cezaya dayanır. Dayanılmaz düzeyde profesyonelce kurgulanmış işkenceler, organ kesmek, öldürmek bu tür cezalardan bazılarıdır. Tarih boyunca, değişik şekiller altında da olsa bu tür cezaların uygulandığı toplumlar, ibret olsun diye verilen cezaların ağırlığını hafifleten, bu cezaların kolayca zulme dönüşebilmesini engelleyen, bu cezaların infazının gerçekleşmesine engel olan çeşitli hukuki düzenlemeler yapmışlardır. Caydırıcı iktidarın cezayı bir caydırma etkeni olarak kullanması, istenen itaatin aciliyeti veya yaygınlı̆̆ı, onun sağlanmasının güçlülüğü ya da önemiyle doğrudan orantılıdır. Bu bağlamda değerlendirildiği zaman, pek çok toplumun ölüme, tecavüze ve diğer fiziki saldırganlıklara engel olmayı zorunlu görmeleri ve potansiyel katille saldırganı, en azından bu eylemler bakımından topluluğun iradesine kesinlikle boyun eğdirmek istemeleri oldukça önemlidir. $\mathrm{Bu}$ nedenle sözü edilen suçlara, sıradan hırsızlığa, gece çevreyi rahatsız etmeye ya da trafik kurallarını çiğnemeye verilenden daha ağır bir yaptırım uygulanmaktadır (Galbraith 2004: 24).

Daha önce de dile getirdiğimiz gibi iktidarın araçları ve kaynakları arasında bütünüyle özelleşmiş olmasa da önemli bir ilişki bulunmaktadır. Kaynak ve araç arasındaki bu ilişki biri diğerini ortadan kaldıran ya da birinin diğeri tarafından bütünüyle belirlendiği bir ilişki olarak düşünülmemelidir. İktidarın ontolojik temelini oluşturuyor olarak görünen ve iktidarın kendilerine bağlı olarak ortaya çıktığı kabul edilebilecek olan kişilik, mülkiyet ve örgütlenmeyle iktidarın araçları arasında karşılıklı olarak etkileşim söz konusudur. Kişilik hem biyolojik hem psikolojik ve hem de toplumsal açıdan bir güç kaynağı olarak değerlendirilmektedir. Kişilik bu yönleriyle caydırıcı iktidar için temel oluşturmaktadır (Galbraith 2004: 45). Kişiliğin bir güç kaynağı olarak kabul edilmesi sadece modern toplumlara özgü bir durum değil; gelişmemiş-uygarlaşmamış, toplumsal, siyasal ve ekonomik ilişkilerin çeşitlilik arz etmediği toplumlar da bile söz konusudur. Hatta siyasal ve ekonomik açıdan farklılaşmanın yaşanmadığı, hayatın her yönüyle ilkel denilebilecek seviyede olan toplumlarda kişilik, özellikle de zora dayalı bir iktidarın uygulanmasında, önemli güç kaynaklarından birisi belki de en önemlisidir. Örneğin, otoriter liderler, yalnızca kişilik 
gücüyle yönetebilmek amacıyla devletin olağan mekanizmasını yıkabilir ya da bir kenara atabilirler. Mussolini bir arkadaşına yazdığı mektupta 'önündeki çalıları temizlemek' için mücadele ettiğini, 'kendisinin güçlü bir adam olduğu için ayaklarının altındaki otlara takılıp düşmeyeceğini' ifade etmektedir (Sennett 1992: 172). Tanrı'nın iktidarı elinde bulunduran insanlara bir tilki kuyruğu değil, süvari kılıcı verdiğini düşünen otoriter yöneticiler, belirli bir üstünlük duygusu, başkaları üzerinde egemenliğe sahip olma zevki, haklı olmanın belirli bir güveni ve tahakküm edici bir huya sahip olma özelliğini kendi karakterlerinin ayırıcı nitelikleri olarak düşünürler (Jouvenel 1997: 150).

Modern toplumda, kişiliğin bileşime girdiği en önemli kombinezon onu koşullandırma gücüyle birleştiren kombinezondur. Etkileyici kişilik, başkaları üzerinde yarattığı kanaat ve oluşturduğu nüfuzla itaati doğurur. Kişiliğin, onu inandırıc1, koşullandırıcı güç haline getiren yönleri nelerdir? Eskiden kişinin kendini yönlendiren ve her ölümlünün erişemediği doğaüstü güçlerle ilişkide olduğu yolundaki o yaygın inanış çok önemliydi. Bu inanış bugün de önemini korumaktadır. Çeşitli din önderlerinin kendilerinin doğaüstü birtakım güçlere sahip olduklarını söyleyerek etraflarına kalabalıkları toplamaları bunun açık örneğidir. Bugün dünyanın birçok ülkesinde din kaynaklı olduğunu söyleyerek doğaüstü güçlere sahip olduğunu iddia eden birçok hareket önderi, kendisine tabi olan insanların iradelerini ortadan kaldırıp özgürce karar vererek eylemde bulunabilmelerini engellemektedir. Kişiliğin mutlak anlamda güç sahibi olduğunun kabul edildiği, toplumsal ve siyasal örgütlenmelerin bu anlayış çerçevesinde şekillendiği toplumlarda yaşayan insanlar, lider ya da efendi olarak kabul edilen kişilerin iradelerine, çoğunlukla gönüllü bir şekilde, itaat ederek yaşamaktadırlar. Bu tür ilişkilerin yoğun olduğu birliktelikler, o ülkelerdeki siyasal örgütlenmelerin toplumsal temellerini oluşturduğu için söz konusu ülkelerdeki siyasal parti ya da grupların liderlerine de kutsallık atfedilmektedir. Böylece, siyasal partilerin oluşumu da yukarıdan aşağıya doğru şekillenmekte ve otoriter hiyerarşik bir yapı ortaya çıkmaktadır. Hatta herhangi bir siyasal partiye oy veren insan, bu işi dinsel bir görevmiş gibi algılayıp kendi siyasal varlığının nedeni olarak oy verdiği partiyi gördüğü için parti 
lideri olarak kabul edilen kişinin hatadan masun olduğuna inanmaktadır (Can 2005: 79). Efendilik ya da önderlik konumunda bulunan insanlar, kendilerinin ulaşmış oldukları mevkilere çalışılarak ulaşılamayacağını ve buralara ulaşmanın biricik yolunun tanrısal esine bağlı olduğunu iddia ederek insanları aldatmakta ve kendilerinde birtakım gizil güçlerin olduğunu söyleyerek insanların akıllarını ve bedenlerini sömürmektedirler. Dinsel kaynaklı olduğunu iddia eden böylesi yapılanmaların hemen hemen hepsinde bu türden ilişkilerin olduğu söylenebilir. Tarihte niceleri, insanlara çok büyük sevgi duyduğunu söyleyen bir hümanist olarak çıkmıştır yola ama sonunda bir kan denizine ulaşmıştır. Cemaatçi ilişkilerin egemen olduğu toplumlardaki sosyal hareketlerin liderleri, genellikle kendileri için bir şey istemediklerini dile getirirler (Rand 1993: 683). İnsan aklının, tanrının iradesi olarak isimlendirdikleri ve kendi arzularınca dile getirdikleri şeye boyun eğmesini isterler. İnsanın değer standardı, Tanrı'yı memnun etmektir, Tanrı'nın standartlarıysa insanın anlama gücünün ötesindedir ve iman gereği kabul edilmek zorundadır. Tanrı'nın standartlarını eleştirmek ya da doğru olup olmadıklarını incelemek amacıyla gösterilecek olan herhangi bir rasyonel çaba lanetlenmiş bir çabadır ve tanrı tarafindan asla kabul görmeyecektir. Tanrıyı memnun etmenin yolu onun yeryüzündeki temsilcilerini memnun etmektir. Çünkü onlar, tanrısal niteliklerle donandıklarına inandıkları için tanrı adına hareket ettiklerini iddia ederler. Dünyadaki insanları yönetecek, iyiyi ve kötüyü, doğruyu ve yanlışı onlara açıklayacak olanlar, tanrının bu seçkin kullarıdır. Kendilerinin tanrının seçkin kulları olduklarını söyleyen bu insanlara göre, dünyadaki diğer insanların biricik görevleri, soru sormaksızın kendilerine itaat etmeleridir. İktidarın kaynakları arasında yer alan kişiliğin etkileyici özelliklerinden daha alt düzeyde yer alan zihinsel yetenekler, açıklık ve kavrayış keskinliği, çekicilik, dürüstlük, nükte, gösteriş ve diğer birçok özellik rol oynar.

Koşullandırma ve ikna gücünü kullanmayı sağlayan niteliklerden bazılarının zekâ ya da ifadeyle doğrudan bir ilişkisi vardır. Kişinin kendisine olan mutlak güveni koşullandırma ve iknada dolayısıyla başkalarının itaatini sağlamada belirleyici bir faktördür. Bunun da zekâ ile zorunlu bir ilişkisi yoktur hatta bazen onun karşıtıyla 
ilişkisi olabilir. Yine de modern siyasi literatürde, iktidarın icrasında kişiliğin rolünü abartma yönünde aşırı bir eğilim görülmektedir. $\mathrm{Bu}$ yanlış eğilimi besleyen birçok neden bulunmaktadır: Örneğin, büyük bir liderin tarihi bakımdan mutlak üstünlügü. Tarihteki büyük liderler arasında başkalarını birleştirme ya da kendi amaçlarına boyun eğdirme yeteneğine sahip pek çok insan vardır. Kişilikleri onlara değiş̧ik şekillerde cezalandırma, ödüllendirme ve koşullandırma yoluna başvurma olanağı vermiştir. Bu gibi insanlar ve bir taklit örneği olarak daha kişiliksiz yöneticiler bile yüceltilirler ve hayranlıkla izlenirler. Böylece zenginliklerine ya da örgütlerine atfedilmesi gereken şey onların kişilikleriyle izah edilmektedir (Galbraith 2004: 48). İktidara kaynaklık etmesi açısından kişiliğin rolünü abartan önemli bir etken de parazit etkisi denilen şeydir. İktidarın araçlarını elinde bulunduran kişi, onun gölgesinde yaşamak ve etkisini paylaşmak isteyenler için doğal bir çekim gücüne sahiptir. Bu kişi, her şeyi kendi kişiliğiyle, liderlik nitelikleriyle başardığını öne sürer, herkes de sonunda buna inanır.

İktidarın bir diğer kaynağı ise mülkiyettir. Mülkiyet iktidarın en kaba biçimde uygulanmasına olanak sağlar. Bu uygulamayla bir kişi bir başkasını, kayıtsız koşulsuz satın alır ve onu kendi iradesine boyun eğdirir. Patron işçisine, zengin şoförüne, baskı grubu kendi siyaset adamlarını bu yolla kendi amaçlarına boyun eğdirir. Mülkiyetle iktidar arasındaki bağ öylesine basit ve dolaysızdır ki eskiden her şey onunla izah edilirdi. Marksizme göre mülkiyet iktidarın yalnızca belirleyici kaynağı değil biricik kaynağıdır. Kapitalist sistemin bütünlüğünü sağlayan bağ dokusudur. Hatta burjuva mülkiyeti sınıf çatışmalarına, birtakım insanların başka birtakım insanlar tarafından sömürülmesine ya da çoğunluğun azınlık tarafından sömürülmesine dayanan üretim ve mülk edinme tarzının en son ve en tam ifadesi olarak görülmektedir (Marx-Engels 2003: 83). Mülkiyet, özel kişilerin elinde kaldıkça, başka hiç kimse iktidara sahip olamaz. Bu nedenle Marksizme göre mülkiyetin kaldırılması gerekmektedir. İktidarın önemli bir kaynağı olan mülkiyetin, iktidarın yozlaşmasında ve iktidarı elinde bulunduranların birer zorba haline gelmelerindeki etkisi dolayısıyla mülkiyet ayrıcalığın ve zorbalığın baş nedenidir. (Proudhon 1998: 257). Memur ya da milletvekillerinin, ihaleye katılan şirketlerce ve yabancı devletler tarafından rüşvetle satın alınması 
durumunda olduğu gibi, iktidarın kötüye kullanılması ya da yetkinin aşılması konusunda yapılan her araştırma, sorunun doğrudan doğruya paranın yani mülkiyetin gayrimeşru kullanımından kaynaklandığını göstermektedir.

Mülkiyet, iktidarın üç kaynağından birisi olmasına karşın yakın geçmişte önemini örgüte kaptırmıştır. Devlette olduğu gibi bütün büyük işletmelerde eskiden mülkiyete, mali kaynaklara bağlı olan iktidar, günümüzde bireylerin iş birliğine, bürokrasiye dayanmaktadır. Yine mülkiyet, iktidarın araçlarını ele geçirmede eskisine göre daha az işe yaramaktadır. Eskiden mülkiyet cezalandırma tehdidiyle itaati sağlayabiliyordu. Özel mülkiyet onu elinde bulunduranlara köleleri, hizmetçileri, serfleri cezalandırma ve işçilerin başkaldırısını kırmak üzere kamu otoritesini göreve çağırma hakkı veriyordu. $\mathrm{Bu}$ uygulamalar kaldırılmış ve yasal desteğini yitirmiştir bugün. Zengin artık parasını oy satın almaya harcamıyor; onun yerine televizyonda reklâm sekansları satın alıyor ve bununla, görüşlerine taraftar bulmayı umuyor. Zenginlik, koşullandırma ve ikna gücüne belli bir ölçüde de olsa her zaman sahiptir. Eskiden zenginlik öyle bir prestijden yararlanıyordu ki onu elinde bulunduran bir iktidar, kazanmak için hiçbir ödül sunma gereği duymuyordu. Zengin kişinin düşünceleri ve sözleri kendiliğinden başkalarının katılımını sağlıyordu. Çünkü zenginlerin ihtişamı, onlara ödüllendirme ve koşullandırma gücünün kapılarını otomatik olarak açacak düzeydeydi. Bugün de kimi zenginler siyaset, ekonomi, kişisel tutum ya da insanlar arası ilişkilerinin zenginliklerinden ve zenginliğin onlara verdiği üstünlük anlayışından dolayı ciddiye alınması gerektiği şeklindeki duyguyu taşımaya devam ediyorlar (Galbraith 2004: 55). Ancak günümüzde insanların gelirlerinin asgari geçim düzeyinin üstüne yükselmiş olması, işsizlik tazminatı, sosyal güvenlik ve emekli sandıkları ödüllendirici iktidarın etkisini yumuşatmış ve onun temeli olan mülkiyetin önemini azaltmıştır. Yine de mülkiyet, her gün milyonlarca insanın çalışma hayatını kendine bağlamaya devam etmektedir. Büyük ekonomik işletmelerdeki yöneticilerin dinamizm ve düşünceleri açısından onlara esin kaynağı olan etkenlerden biridir.

Mülkiyete ve kişiliğe dayalı iktidarın çöküşü, örgütün yükselişiyle doğrudan bağlantılıdır. Bu iki iktidar şeklinin örgütün kaynaklık ettiği iktidar önünde büyük 
ölçüde gerilediği ve güç kaybettiği bir gerçektir. İktidarın diğer iki kaynağına göre örgüt, özellikle modern çağda büyük önem taşımaktadır. Sınıf olsun herhangi bir grup olsun hiçbir kolektif topluluk, iktidarı kendi başına kullanamaz kullanamayacaktır. Bunun için de başka bir faktör gereklidir: Örgüt. Devlet olarak ortaya çıkan şekli de dâhil olmak üzere örgüt, her iktidarın nihai kaynağıdır. Gerçekten de mülkiyet ve kişilik ancak örgütten destek alarak insanı iktidara ulaştırır. Örgüt, caydırıcı iktidarı kullanabilir. Mülkiyetle olağan ilişkisi içinde ödüllendirici iktidarı elinde tutar. Tüm bunlardan ayrı olarak ve özellikle modern şekliyle ikna edici ve koşullandırıcı iktidar işlevi görür. İkna etme ve koşullandırma işlevi, örgütün tüm var oluş nedenidir. Örgütün belli bir amacı güden birey ya da grupların iş birliği olarak tanımlanması, onun temel karakteristiğini ortaya koymaktadır. Üyeleri, genellikle örgüt dışındaki birey ya da grupların itaatini sağlamaktan ibaret bir ortak amacı izlemek üzere, bağlılıkları farklı derecelerde olsa da topluca örgütün iradesine boyun eğmişlerdir (Galbraith 2004: 60).

Aslında örgüt düşüncesi, genel ve birbirleriyle uyumlu birtakım kurallara tabidir. Örgüt, caydırıcı iktidarı kullanabilir; mülkiyetle olan ilişkisi bağlamında ödüllendirici iktidarı elinde tutar; özellikle modern şekliyle ikna edici ve koşullandırıcı iktidar işlevi görür. İktidar kaynağı olarak örgütün temel özelliklerinden birisi, onun iki farklı varoluş biçimi arasındaki simetride gizlidir: Örgüt amaçlarına kendi içinden hizmet etmedikçe, üyesi olmayan insanları o amaçların hizmetine sokamaz. Örgüt iktidarının dış dünyadaki güç ve yaptırıcılığı, kendi içinde elde ettiği itaatin derinlik ve sağlamlığına bağlıdır. Bir örgütün gücü, diğer iktidar şekilleriyle kurduğu iş birliğiyle doğru orantılıdır. Herhangi bir örgüt, caydırıcılığa, ödüllendiriciliğe ve koşullandırıcılığa etkili bir şekilde sahipse güçlüdür, değilse zayıftır. Örneğin, güçlü ve kapsamlı bir örgüt olan devlet, genellikle iktidarın her kaynağını etkin bir şekilde kullanmaya çalışır. Merkezden çevreye doğru tahakküm akışını ve çevreden merkeze doğru itaat akışını sağlamak için gerekli olan askeri ve ideolojik güçler şeklinde değerlendirilen, biçimi ve etkinliği bakımından en yüksek düzeyde bir örgüt olan devlet, memurlarını kendisine itaat etmeye zorlar (Lourau 2001: 14). Devlet, yalnızca memurları değil; egemenliği altında bulundurduğu insanların hepsini kendisine itaat ettirmek için iktidarın gerekli 
kıldı̆̆ı her aracı devreye sokmaya çalışır. Ancak devletin yalnızca kuvvete dayanarak yönetme kapasitesi her zaman kısıtlı olmuştur. Tamamen baskıcı, her yerde hazır ve nazır devlet mitosu, toplumun ezilen kesiminde toplumsal tevekküle yol açan bir korku ve güçsüzlük duygusu yaratarak devlet mekanizmasına çok iyi hizmet eden bir kurgudur. Devlet iktidarı karşısındaki korku ve kayıtsızlık bu iktidarı olanaklı kılan toplumsal koşullandırmanın ürünleridir (Bookchin 1994: 187). İnsanları koruma ve yönetme işlevleriyle ortaya çıkmış olan devlet açısından iktidar, en basit haliyle 'biraz rıza eklenmiş güç’ olarak tanımlanır. Koruma için önkoşul güçtür. Ancak tek başına güç, düzen sistemini sürekli kılamayacağından iktidar, güç ve rızanın karışımından ortaya çıkar. Sonuç olarak eğer düzen, adalet ile en yüksek noktasına erişecekse, iktidar da otoriteye yani meşru iktidara dönüşmelidir. İster bir ülke olsun ister bir şirket veya başka herhangi bir kurum olsun aşağı yukarı sağlam ve yönetilenlerin çoğunluğu tarafından benimsenen düşünce ve ideallere dayanmayan bir iktidar organı varlığını uzun süre devam ettiremez. Yani kendisini destekleyecek bir yapıdan mahrum olan iktidar sonunda kendini yıkar. Meşru dayanağı olmayan bir iktidarı ellerinde bulunduranlar çılgınlaşır ve bu gücü meşru bir şekilde kendinden sonra gelenlere aktaramazlar (Berle 1980: 32). Hangi şekilde olursa olsun herhangi bir düşünce sistemi tarafından desteklenen ya da desteklenmeyen her iktidar zaman içerisinde doğası gereği yozlaşır. Her ne kadar koruma, düzen ve adalet araçları iktidarın meşruiyeti için önemli dayanaklar olsa bile devlet iktidarını da bu yozlaşmanın dışında tutma olanağı yoktur. Dolayısıyla biz burada genel olarak iktidarın yozlaştırıcı özelliğini, özelde siyasal iktidarın nasıl yozlaştırdığını, çeşitli siyasal yozlaşma örnekleriyle, göstermeye çalışacağız.

\section{İktidar ve Yozlaşma}

İktidara sahip olanlarda ve ona maruz kalanlarda, özellikle siyasal iktidar alanında yöneten ve yönetilenlerde ortaya çıkacak olan yozlaşma, iktidarın varlığına neden olan kaynaklar ve iktidarın uygulanmasında müracaat edilen araçlardan bağımsız olarak ele alınamaz. İktidar kendi başına bir şey olarak düşünülemeyeceği için onun ortaya 
çıkmasına neden olan kaynaklar ve ona uygulanma olanağı veren araçların zaman içerisinde geçirmiş olduğu değişim ve dönüşümler iktidar ilişkilerinin de başkalaşımına neden olurlar. İktidar ilişkilerinde en fazla değişime ve dönüşüme uğrayan iktidarın uygulanmasını sağlayan araçlardır. İktidarın araçları ne şekilde değişirse değişsin, iktidarın doğasında herhangi bir değişiklik meydana gelmez. Dolayısıyla iktidarın doğası gereği yozlaştırma özelliği de iktidarın mevcudiyetine bağlı olarak varlığını devam ettirir.

İktidarın kaynağı ve araçlarının karşılıklı ilişskilerine dayalı olarak siyasal kararların alınma sürecinde ortaya çıkan siyasal yozlaşma, siyasal iktidarın doğal bir sonucu gibi görünmektedir. Kaynaklar ve araçlar arasında oluşacak olan basit bir ilişkiye göre kişilik, genellikle zor kullanma ve caydırma araçlarını tercih etmektedir. Bir başka anlatımla caydırıcı bir güce sahip olma genellikle kişiliğin kendisine müracaat ettiği araçların başında gelir. Siyasal ilişkilerin daha ilkel düzeyde yaşandığı geleneksel toplumlarda kişilik hem bedensel gücü hem de manevi bir otoriteyi temsil eder konumda bulunmaktadır. Toplumsal ve siyasal değişimin yok denecek derecede yavaş gerçekleştiği bu toplumlarda siyasal iktidarı elinde bulunduran kişi ya da kişilerin, yönetilenleri istedikleri doğrultuda yönlendirme ve bu yozlaşmış ilişsi biçimini kemikleştirme ihtimalleri oldukça yüksektir. İktidarın kaynakları arasında yer alan kişilik, sadece geleneksel toplumlarda değil, toplumsal ve siyasal ilişkilerin karmaşık hale geldiği gelişmiş toplumlarda da siyasal karar süreçlerinde etkin rol oynar ve caydırıcı olma özelliğini taşımaya devam eder.

İktidarın kaynaklarından birisi de mülkiyettir. Siyasal bir iktidar kaynağı itibariyle mülkiyete dayalı olarak ortaya çıkmışsa bu iktidar, kişilerin eylemlerini değiştirmenin yolu olarak daha çok ödüllendirmeyi tercih eder. Siyasal kararların alınmasında mülkiyetin yani ekonomik gücü elinde bulunduranların etkileri tarih boyunca bütün toplumlarda belirleyici rol oynamıştır. Mülkiyeti mutlak bir güç olarak düşünen yöneticilerin, zamanla hesap sorulamaz zorbalar haline geldikleri bir gerçektir. Dolayısıyla mülkiyetin gücü oranında yöneten yönetilen arasında bir anlamda efendiköle ilişkisi şeklinde yoz bir ilişki ortaya çıkmaktadır. Bu tür bir ilişki, iktidar 
olgusunun her iki tarafinda yer alanları etkileyerek, o insanların zamanla insani doğalarından uzaklaşmalarına sebep olur.

İktidarın kaynaklarından bir diğeri ise örgüttür. İktidarını var kılmak ve sürekli hale getirmek için çoğunlukla ikna etme-koşullandırma yolunu kullanan örgüt, günümüz toplumlarında iktidarın diğer kaynaklarından daha önemli bir hale gelmiştir. Çünkü modern dünyadaki iktidar, çoğunlukla örgütlere dayalı bir iktidardır. Özellikle siyasal iktidar alanında örgüt, iktidarın hem kaynağı hem de kullanıcısı durumundadır. Siyasal iktidarın en büyük ve en yüksek temsilcisi olan devlet de nihayetinde bir örgüt olarak karşımıza çıkmaktadır. Çeşitli kurum ve kuruluşları (örgütleri) kendi içerisinde toplayan devlet, en karmaşık ilişki biçimlerini bünyesinde barındıran bir örgüt olması nedeniyle yozlaşmanın en fazla yaşandığı bir yapıdır. Karmaşık ilişkiler ağı ve devasa yapısıyla devlet, hangi yönetim şekline dayanırsa dayansın siyasal yozlaşmanın farklı şekilleriyle karşılaşılan bir kurumdur. Çünkü insani ilişkilerin en fazla denetime tabi olduğu ve bir o kadar da yasaların, ahlaki ve dini kuralların ihlal edildiği kurum yine devlettir.

İnsani ilişkilerin her çeşidinde bir şekilde iktidarın ortaya çıkması mukadderdir ve iktidarın yozlaştırıcı niteliği onun doğasında vardır. Ancak asıl iktidar, çalışmamız boyunca doğrudan veya dolaylı olarak temas ettiğimiz, siyasal iktidardır. Siyasal iktidar, doğrudan doğruya insan-özneler arasında oluşan iktidar olması nedeniyle en fazla yozlaştırıcı etkiye sahiptir. Siyasal iktidarın, iktidarı kullananlar ve o iktidarın gücüne maruz kalan insanlar açısından hayatın her cephesine yönelik bozucu ve dejenere edici etkisi siyasal yozlaşma olarak değerlendirilmektedir. Siyasal yozlaşma, iktidarın gücüne maruz kalan insanlardan daha çok iktidarı kullananların yaşadığı negatif bir değişim sürecidir. Bu tür bir değişim, öncelikle kamusal hizmetlerin yerine getirilmesinde yaşanan rüşvet, irtikâp, zimmet suçu, akraba kayırıcılık, siyasal yandaşlık, yolsuzluk vb. durumlarda ortaya çıkmaktadır. Ancak kamuya yönelik hizmetlerde karşılaşılan yolsuzluk sadece parasal konularda değil, söz konusu hizmetlerin her türünde gözlenmektedir. Kamusal yetkinin meşru olmayan kullanımını içeren davranış ve eylemlerin tümünü kapsayan yolsuzluk, yozlaştırıcı etkisini hem siyasal gücü 
kullananların hukuk ve ahlak kurallarını ihlal etmelerinde hem de iktidarın nesnesi durumunda bulunan insanların iktidar sahiplerine yönelik olumsuz tutumlar geliştirmelerinde ve nihayet süreç içerisinde toplumsal ilişkilerin her türünde göstermektedir.

Siyasal yozlaşma, sadece rüşvet, yolsuzluk gibi parasal konularda değil aynı zamanda iktidarı elinde bulunduran insanların yapmaları gereken işleri yapmamaları durumunda ya da yapmamaları gereken işleri yapmaları durumunda da karşımıza çıkmaktadır. Siyasal iktidarı kullanma yetkisine sahip olan insanların, değişik faktörlerin etkisiyle bilincinde olarak ya da olmayarak asli görevlerini yerine getirmemeleri sadece siyasal aktörlerin değil aynı zaman da siyasal kurumların yozlaşmasına da zemin hazırlamaktadır. Kurumların ve bireylerin yozlaşması ise birbirinden bağımsız işleyen bir süreç değil; karş1lıklı etkileşime dayalı bir olgudur. Rüşvet, zimmet, adam kayırmacılık gibi siyasal nitelikli kirlilikler, her ne kadar aktörlerin kamusal işlerini ifa ederken yaşadıkları yolsuzluk durumu olarak görülse de zamanla o insanların hayatlarının her alanına nüfuz ederek karakterlerinin ayrılmaz nitelikleri haline gelmektedir. $\mathrm{Bu}$ kişiler, temelde kişisel çıkar sağlama amacıyla toplumda geçerli olan ahlaki, hukuki, dini ve her türlü kültürel normu ihlal edici eylemlerde bulunmaları nedeniyle giderek bu kurumların etkinliğinin azalmasına ya da bütünüyle ortadan kalkmasına sebep olmaktadırlar. İşlevsizleşme ve kötürümleşme sonucu yozlaşan kurumlar, bu kurumlarda yer alan insanların da (siyasetçiler, bürokratlar, çıkar ve baskı grupları) zamanla yozlaşmalarına sebep olmakta ve olumsuz etkilerini toplumun her kesimine yaymaktadır.

Siyasal gücü elinde bulunduran insanların yani iktidar sahiplerinin yozlaşmasının sebeplerinden birisi de kendilerine ve yakınlarına sağladıkları ayni veya nakdi çıkarlardır. Yine de çıkar sağlamayı sadece maddi şeylerle sınırlandırmamak gerekir. Çünkü siyasal yozlaşma, kamusal işlerin yerine getirilmesinde kamunun zararına olacak şekilde özel çıkar sağlamaya yönelik her türlü eylem ve davranışın sonucunda ortaya çıkar. Dolayısıyla siyasal yozlaşma, çoğunlukla gizli bir şekilde işleyen bir süreçtir ve doğası gereği gizliliği her zaman içerisinde barındırır. Ancak siyasal yozlaşmanın 
hoşgörü ile karşılandığı toplumlarda kendisini aşikâr etme gibi bir huyunun olduğu da göz ardı edilmemelidir. Sadece baskıcı toplumlarda değil, siyasal özgürlüklerin yaşandığı toplumlarda da siyasal yozlaşma olacağı için monarşi, oligarşi ve hatta demokratik toplumlarda da kimi dönemlerde siyasal yozlaşmanın hoşgörüyle karşılandığı bir gerçektir.

Siyasal süreç içerisinde ortaya çıkan siyasal yozlaşma, yerine ve zamanına göre çok değişik şekillerde görünüm kazanmaktadır. Örneğin, bir siyasal yozlaşma durumu olan rüşvet, demokratik veya antidemokratik neredeyse her toplumda karş1laşılan bir sorundur. Rüşvet, kişisel çıkar için görev ve yetkinin kötüye kullanılmasıdır. Kamusal alanda çeşitli görev ve yetkilere sahip olan insanların, parasal veya başka türlü menfaatler karşılığında birtakım kimselere diğerleri aleyhine olacak şekilde ayrıcalıklı iş yapmaları açıkça bir rüşvet durumudur. Kamu kurum ve kuruluşlarında rüşvet olayı ya bizzat kamu görevlisinin talebine bağlı olarak veya ilgili kurumda iş yaptırmak zorunda olan kişilerin, işlerinin hızlandırılması ya da meşru olmayan bir durumun onaylanması vb. adına kamu görevlisine yapmış olduğu öneri sonucunda gerçekleşmektedir. İki taraf arasında gerçekleşen bir değiş-tokuş hali olarak düşünülen rüşvet, tarihin en eski dönemlerinde bile varlığını devam ettirmiş bir siyasal yozlaşma türüdür. Denilebilir ki yöneten yönetilen ilişkisinin ortaya çıkmasıyla birlikte rüşvet de var olmuştur. Rüşvet suçunun özel bir şekli de irtikâptır. Rüşvet, iki tarafın rızasıyla gerçekleşen bir siyasal yozlaşma türü iken irtikâp, kamu görevlisinin tek taraflı olarak karşısındakini rüşvet vermeye zorlamasıdır.

Bir diğer siyasal yozlaşma şekli de zimmet yani kendisine emanet edilen şeyi kendi malı gibi kullanmaktır. Siyasal terminolojide zimmet, kamu kurum ve kuruluşlarında yetkili bir insanın kamusal bir kaynağı gayri meşru bir şekilde yani yasalara aykırı olarak kişisel çıkarı adına harcaması veya kullanmasıdır. Örneğin bir kamu görevlisinin kendi özel aracının yakıt sarfiyatını, bulunduğu konumun kendisine sağladığı yetkilere dayanarak, devletin kaynaklarından karşılaması bir tür zimmettir ve bu hırsızlıkla eş anlamlıdır. Rüşvet, irtikâp ve zimmet her ne şekilde gerçekleşirse gerçekleşsin siyasal yozlaşmanın hem nedeni hem de sonucu durumundadırlar. 
Siyasal kararların alınma sürecinde ortaya çıkan diğer bir siyasal yozlaşma şekli de adam kayırmacılıktır. Adam kayırmacılığın en yaygın şekli nepotizm olarak ifade edilen akraba kayırmacılıktır. Akraba kayırmacılık çoğunlukla siyasal parti, grup ve yapılarda görülmektedir. Akraba kayırmacılık, genellikle siyasal kayırmacılığın yaşandığı durumlarda ön plana çıkmaktadır. Siyasal partilerin iktidara geldikten sonra kendilerine destek olan insanlara çeşitli şekillerde ayrıcalıklı davranarak bu kişilere haksız yere menfaat sağladıkları çokça tanık olunan durumlardandır. İktidara gelen herhangi bir siyasal partinin yöneticisi veya yöneticilerinin, kendi akraba ya da yakınlarını yetenek, başarı ve eğitim düzeylerini dikkate almaksızın, kendi çabalarıyla hiçbir zaman ulaşamayacakları makamlara getirmeleri akraba kayırmacılığın en açık örneğidir.

Burada sınırlı sayıda verdiğimiz siyasal yozlaşma örneklerinden de anlıyoruz ki siyasal iktidarlar, insani ilişkilerin en karmaşık hale geldiği ve yozlaşmanın en çok yaşandığı yapılardır. Ancak yozlaşma, sadece siyasal ilişkiler ağı olarak kabul edilen siyasal iktidarlara özgü bir durum olmayıp, iktidar ilişkilerinin yaşandığ 1 her yerde ortaya çıkmaktadır.

\section{Sonuç Yerine}

Devletin koruma, düzen, adalet amaçları yönetimin güç, iktidar ya da otorite araçları ile karşılanmaktadır. Amacın araçları meşru kıldı̆̆ı söylense de bu doğru değildir. Çünkü bazı araçlar öylesine ahlâkdışıdır ki hiçbir amaç onları haklı çıkaramaz. Ahlaki yargılarımızı hedef ve yöntemlere aktardığımızdan, araçlar amaçları anlamsız kılabilir. Özellikle devlet yönetimi alanında, bunun olası etkileri çok daha kapsamlıdır. Devlet, kullandığı araçların doğasından diğer kurumlardan daha fazla etkilenir ve söz konusu araçların istismarı amaca zarar verebilir. Bunun gerçekleşme olasılı̆̆ı, iki olgudan kaynaklanır: Devletin gücü kendi tekeli altına alma iddiası ve yönetimin işlevlerini yerine getirecek devlet temsilcileriyle resmi görevlilerin seçimi konusu. $\mathrm{Bu}$ etkenler bir araya geldiklerinde sonuç, güç tekelini bürokratların eline teslim etmek anlamına gelir. $\mathrm{Bu}$ nedenle baskı araçları görevlilerin elleri altında olduğundan, 
toplumun geri kalan kesimi resmi görevlilerin insafına kalmış olabilir. Koruma, gücün güce karşıtlığına dayandığı için, kendini korumayı kurumsallaştırmış bir grup, fiziksel denetim araçlarının kullanımını resmi görevlilerine bırakmaktan kaçamaz. Resmi görevlilere bırakılmış olan bu gücün çoğunluğun aleyhine dönmeyeceği nasıl garanti edilebilir? Bir başka ifadeyle ‘koruyucuların kendisine karşı bizi kim koruyacak?’ Güç ateş gibidir. İnsanoğlunun hizmetine sunulabileceği gibi ona en büyük zararları da verebilir. Güç tehlikeli bir efendidir, ateş gibi bir kez denetimden çıktığı zaman sınırsız bir yıkım potansiyeli taşır.

İktidar kimi zaman güçle eş anlamlı kullanılsa bile, güç ve iktidarı aynı şeyler olarak düşünmek yanıltıcı olur. Ancak güç, iktidarın kaynakları ve araçlarıyla içiçelik göstermektedir. Söz konusu araçlar ve kaynaklardan bağımsız olarak düşünülemeyecek olan iktidar, kendisini kullananların gücü oranında yozlaştıracaktır. Öyleyse, yozlaştırmanın iktidarın doğasından kaynaklandığı söylenebilir. Lord Acton'un dile getirdiği gibi 'iktidar yozlaştırır, mutlak iktidar mutlaka yozlaştırır.' (Himmelfarb 1949: XV). İktidarın yozlaştırması iki yönlü bir yozlaştırmadır. Yozlaştırma hem iktidarın uygulayıcıları açısından hem de iktidarın etki-alanında bulunanlar açısından geçerli bir durumdur. İktidar ilişkilerinin bulunduğu her yerde bir tür yozlaştırmadan söz edilebilmesine karşın; gerçek ve yaygın anlamında iktidar ilişkileri siyasal iktidar alanında var olduğu için asıl yozlaşma da bu alanda meydana gelmektedir.

İktidar yozlaştırır. İktidarı özel bir alanda, siyasal iktidar alanında değerlendirdiğimizde; başlangıçta iyi niyetlerle iktidara gelen birçok insanın zamanla iktidar ilişkilerinin yapısı ve niteliğinden dolayı bir anlayış değişikliği yaşadığı ve bu durumun da o kişinin söylem ve eylemlerine yansıdığı bir gerçektir. Nice kibar ve zarif insanların, iktidar ilişkilerinden dolayı söz ve eylem açısından birer zorba haline geldiklerine tarih her zaman tanıklık etmiştir. İktidar bir taraftan gücü elinde bulundurmaktan dolayı gücü elinde bulunduranları yozlaştırıcı bir etkiye sahiptir, diğer taraftan, iktidarı elinde bulunduranların çeşitli nedenlerle muktedir olamayışlarından dolayı yozlaştırıcı bir etkide bulunur. 
Gücü elinde bulunduranların bu güçlerini mutlak bir güçmüş gibi görüp zamanla zorbalaştıkları ve iktidara maruz kalanlar üzerinde dediğim dedik bir tavır sergilemeye çalıştıkları bir gerçektir. Ancak iktidarın alanı içerisinde bulunanların her zaman güce maruz kaldıklarını söylemek doğru değildir. Çünkü güç sözcüğü, etkisi bakımından doğrudan ve burada olan bir şeyi, iktidardan daha dolaysız bir biçimde zorlayıcı bir şeyi getirir akla. Güç, kendisine zaman tanındığında iktidar haline gelir ama kriz anı, geri dönüşsüz karar anı gelince güç çıplak güç haline geri döner. İktidar daha geneldir ve güçten daha geniş bir alanda işler. İktidar, güçten çok daha fazlasını içerir ama daha az dinamiktir. İktidar daha törenseldir, hatta belirli bir sabır ölçüsü vardır. Güç ve iktidar arasında bulunan ayrım kediyle fare arasındaki ilişkiyle çok basit bir şekilde örneklendirilebilir. Kedi, gücü, fareyi yakalamak, onu ele geçirmek, pençelerinin arasında tutmak ve nihai olarak da öldürmek için kullanır. Ama fareyle oynarken bir başka etken daha vardır. Kedi bazen farenin gitmesine izin verir, biraz kaçmasına, hatta arkasını dönmesine firsat tanır; bu süre boyunca fare artık güce maruz değildir. Ancak hâlâ kedinin iktidar alanının içerisinde bulunmaktadır ve her an tekrar yakalanabilir. Eğer fare derhal uzaklaşırsa; kedinin iktidar alanından çıkar ama artık ulaşılamayacak olduğu noktaya varana kadar hâlâ kedinin iktidar alanının içerisindedir. Kedinin egemen olduğu saha, fareye yaşattığı umut anları, bir yandan da bütün bu zaman zarfında onu yakından izlemeyi sürdürmesi ve onu yok etmeğe gösterdiği ilgiyi ve yok etme niyetini asla elden bırakmaması iktidarın bizzat kendisi olarak nitelendirilebilir. Bir başka anlatımla mekân, umut, dikkatle izleme ve yok etme niyetine gerçek iktidar gövdesi ya da iktidarın kendisi denebilir (Canetti 1998: 281).

İktidar yozlaştırır. İktidara gelme ya da iktidarı elde etme arzusu, basit bir arzu olmadığı gibi, zamanla, iktidara sahip olan birçok insanda bir hırsa dönüşür. İktidara gelen ve elde ettiği iktidarı bırakmak ya da başkalarına devretmek istemeyenler, çoğunlukla hırslarının kurbanı olurlar. İktidar, doğası gereği, iktidarı icra eden insanları kendi oluşum ve işleyiş koşulları doğrultusunda değiştirip dönüştürür. $\mathrm{Bu}$ insanlar zamanla öyle bir hale gelirler ki kendi çıkarlarının dışında hiçbir şeyi düşünmez olurlar. İktidarı ellerinde bulundurma isteği ve çıkarlarını koruma telaşası onların gözlerini kör 
eder. Sürekli olarak iktidarda kalma amaçları için her türlü aracın meşru olabileceğine inanmaktan geri durmazlar. İktidarı ellerinde bulunduran bu insanlar, bencil değil özgeci olduklarını ve yönetilenlerin çıkarı için belli ideallere ulaşmaları gerektiğini iddia ettikleri müddetçe üstünlüklerini sürdürmeye devam ederler. $\mathrm{Bu}$ insanlar, iktidarı kullandıkları kesime karşı, sürekli kendi çıkarlarını koruyor izlenimi vermemek için değişik kişiliklerde ortaya çıkarlar. Profesyonel bir politikacı iseler her gittikleri yere ve yöreye göre ağız değiştirip yeni yüzlerle orada bulunan insanların karşısına çıkarlar. Bu kişilerin herhangi bir ilkeleri yoktur. Bırakın kalabalıkları, tek tek kişilere karşı bile oldukça farklı davranıp farklı yüzlerle ilişkilerini devam ettirmeğe çalışırlar. Bu nedenle böyle insanların iki yüzünden değil, iki yüz yüzünden söz etmek daha doğru olur. Her yüz onlar için bir maske durumunda olduğundan farklı olduklarını düşündükleri kişi ve gruplara karşı bir maskeyi çıkarıp diğerini takarlar. Böylece iktidarın yozlaştırdığı bu kişilerin karşılaştığınız yüzlerine ya da maskelerine göre onları ne ise o olarak ifade edecek bir tanım yapamazsınız. Belirli bir tanımları olmadığı için her zaman ve mekâna göre maske değiştirmeleri dolayısıyla onlara güvenecek olan kişiler de her seferinde yanılacaklardır. $\mathrm{O}$ an ki maskeye göre yaptığınız tanım, birkaç saat ya da bir gün sonraki maskeye uymayacağı için siz, eskiyip atılmış ya da bir başka yerde kullanılmak üzere bir kenara bırakılmış maskeyle kalakalırsınız.

Yozlaşma, yapay bir durum olup aslından uzaklaşma anlamına geldiği için iktidarın yozlaştırdığı bu insanların herhangi bir orijinalitesi yoktur. Kendilerine özgü ve bütünüyle doğalarının gereği olan bir şeyleri kalmadığı için bu insanlar kişilikleri itibariyle de parçalı bir görünüm arz ederler. Bu parçalı ve belirlenemeyen kişilikleri doğrultusunda ortaya koydukları söz ve davranışları da onların karşısında bulunan insanlar tarafından ya hiç anlaşılmayacaktır veya o tür insanlara benzemeye çalışanlar tarafından anlaşılıyormuş muamelesi görecektir. Özellikle totaliter-faşist rejimlerde bu kişilere karşı kralın çıplak olduğunu söyleyecek kimse çıkamadığından dolayı sözü edilen çok yüzlü kişiler, güçsüzlerin gücünden yararlanarak kendi iktidarlarını devam ettireceklerdir. 
İktidar yozlaştırır. İktidarı elinde bulunduran kişi ya da kişilerin zamanla rantiyecilik duyguları gelişir ve böylece başkalarının emeğine göz dikerler. Çünkü onlar haksız kazanca bayılırlar. Uzun yıllar iktidarda kalabilmeleri için iktidarın otoritesini kullanarak devletin elindeki iktisadi kaynaklardan taraftarlarının cömertçe yararlanmalarını sağlarlar. Böylece kendilerinin etrafında her koşul ve durumda onlarla hareket edecek ve onlara her türlü desteği sağlayacak bir ağ oluştururlar. İktidarın yozlaştırdığg bu kişilerin ilkesel bir tutarlılıkları ve temel ahlaki değerlere bağl1lıkları gibi bir durumları söz konusu olmadığı için yalan söylemeye de o derece yatkınlıkları vardır. İktidarda bulunmak için her yolun meşru olduğunu düşünen bu insanlar, gücün rozetten ve silahtan değil yalan söylemekten geldiğine ve iktidarı daim kılmanın yolunun büyük yalan söylemekten ve başkalarının bu yalanlara katılmalarını sağlamaktan geçtiğine inanırlar. İktidarı elinde bulunduran bu yozlaşmış kişiler, yalanlarını gerekçelendirebilmek için değişik yol ve yöntem bulma becerilerine sahip kişilerdir. Ancak bu kişilerin siyasi etkinliklerinde herhangi bir ilkeye bağlı olmayışları ve kuşatıcı bir takım ahlaki değerlerden bütünüyle uzak olmaları, iktidar koltuğunda oturdukları ve kamu gücünü kullandıkları müddetçe yıkıcı, tahrip edici araçlara dönüşmektedir. İktidarın yozlaştırdığı bu kişiler, kendilerine benzemeyen ve iktidara talip olan başka insanları çeşitli entrika ve dalaverelerle ya yıpratıp ortadan kaldırmaya veya o insanları kendilerine benzetmeye çalışırlar. Farklı düşüncelerin ve farklı düşünenlerin var olan düzeni sarsabileceğinin bilincinde olan bu insanlar, her zaman mevcut durumun devamından yanadırlar.

İktidar, büyük veya küçük her durumda ve her yerde vardır ve aynı yasalar çerçevesinde varlığını devam ettirir. Uluslararası düzeyde üretim yapan bir şirketin başkanı veya yerel bir bankanın müdürü, kendi etkinlik alanı içinde karar alıp emirler verirken, bir devletin yöneticisi durumunda olan kişinin iktidarını uygulama tarzına benzer bir şekilde hareket eder. Kuşkusuz bu insanların sahip olduğu gücün boyutları, devlet başkanı ya da başbakanın elinde bulunan iktidar yetkisine göre oldukça sınırlıdır. $\mathrm{Bu}$ durumda bile söz konusu insanlar aynı kurallara tabi olarak iktidarlarını sürdürürler. İktidarlarını sınırlı bir çerçevede bile olsa yürüten insanların elindeki güç, bir düşünce 
ya da ahlak sistemi tarafindan desteklenmiyorsa ya kendi kuvvet ve sağlamlığını dolayısıyla gerçekle olan ilişkisini kaybeder veya gücü kullananların yozlaşması neticesinde etkisiz hale gelir. Demek ki iktidarı elinde bulunduran insanların çevresindeki hayatla rasyonel bir ilişki kurmadıkları müddetçe yozlaşmalarını engelleyecek bir durumdan söz etme olanağı yoktur. Bir ilişki olarak ortaya çıkan iktidarın yozlaşması, taraflardan her ikisini de etkiler ve yozlaşmanın alanı genişlemiş olur. Dolayısıyla nerede iktidar varsa orada yozlaşmanın da var olduğu söylenebilir. Daha önce de ifade ettiğimiz gibi iktidarın yozlaşması ve yozlaştırması onun doğası gereğidir. İktidar ne derece kaba ve şiddetli olursa yozlaştırma gücü de o derece artar. İktidara yönelik yapmış olduğumuz bu çözümleme ve değerlendirmeler neticesinde diyebiliriz ki iktidarın, özellikle siyasal iktidarın yozlaşması ve yozlaştırmasının en önemli sebebi, iktidarın sınırlandırılmamasıdır. Sınırlandırılmayan iktidar salt bir güç olarak ortaya çıkar. Dolayısıyla salt güç, güce maruz kalan iktidar nesnelerinin (iktidarın bilincinde olan insanların) hareket imkânını daraltır yani özgürlüklerini çiğnemiş olur.

Tarih boyunca özgürlüğe yönelik en büyük tehdit siyasal iktidardan yani devletten gelmiştir ve bundan sonra da öyle olmaya devam edecek gibi görünmektedir. Demek ki bir yerde özgürlüğün teminat altına alınabilmesi için otoritenin, kamu iktidarının sınırlanması gerekir. İktidarın sınırlanmaması iktidarı zamanla yozlaştıracaktır. Özgürlüğün korunabilmesi için iktidarın yozlaşması önlenmelidir. İktidarın yozlaşması ve yozlaştırması her yerde olacağı için toplumsal hayatımızı; özellikle siyasal hayatımızı iktidarın sınırlandırılması esası üzerine bina etmeliyiz. İktidar meselelerinde insanlar genellikle kendileri gibi olanların iktidarda bulunmasını arzu ederler. Bunun hem kendileri hem de mesela içerisinde yaşadıkları toplum ve memleket için iyi olacağını düşünürler. Başka bir ifadeyle iktidarda onlar gibi olanlar varsa endişe etmeye gerek olmadığını sanırlar. Oysa Lord Acton bunun yanlış olduğunu ifade etmektedir. İktidarda kimin olduğunu bırakıp iktidarın sınırlı olup olmadığına bakılması gerektiğini öğütlemektedir. Lord Acton'ın düşüncesi açısından bakıldığı zaman siyasi iktidarın sahibinin inanan $\mathrm{m}$ ateist mi, laik mi anti laik mi olduğunun bir önemi yoktur. Bunlar, 
aslında yönetilenleri ikinci derecede ilgilendirecek şeylerdir. İlk olarak bakılması gereken şey iktidarın sınırlı olup olmadığıdır. İktidar sınırlı değilse iktidar sahipleri kişisel özellik ve inançları ne olursa olsun yozlaşacaktır. Bu yozlaşma, beraberinde bir sürü sıkıntı yaratacaktır. Özgürlügün gasp edilmesi bunlardan biridir. Yolsuzluk, tahakküm ve diğer insan haklarının çiğnenmesi de yozlaşmanın neticesi olarak ortaya çıkacaktır. Bu nedenle iktidarlar mutlaka ama mutlaka sınırlı olmalıdır. İktidar sahibinin veya iktidarı kullanan grupların özellikleri ne olursa olsun bu böyle olmalıdır. 


\section{KAYNAKÇA}

AKAL, Cemal Bali (1998). İktidarın Üç Yüzü, Ankara: Dost Kitabevi.

BARRY, Norman P. (2003). Modern Siyaset Teorisi, çev. M. Erdoğan-Y. Şahin, Ankara: Liberte Yayınları. Yayınları

BERLE, Adolf A (1980). Iktidar, çev. Nejat Muallimoğlu, İstanbul: Tur

BOOKCHIN, Murray (1994). Özgürlüğ̈̈n Ekolojisi, çev. Alev Türker, İstanbul: Ayrıntı Yayınları.

CAN, Nevzat (2005). Özgür Birey Sınırlı Devlet, Ankara: Hece Yayınları.

CANETTI, Elias (1998). Kitle ve İktidar, çev. G. Aygen, İstanbul: Ayrıntı Yayınları.

CONNOLLY, William E (1983). The Terms of Political Discourse, Princeton, New Jersey: Princeton University Press.

DE JOUVENEL, Bertrand (1997). Ikktidarın Temelleri, çev. Nejat Muallimoğlu, İstanbul: Birleşik Yayıncılık.

FOUCAULT, Michel (1991). Discipline and Punish. London: Penguin Books.

FOUCAULT, Michel (2000). Özne ve Íktidar. Çev. I. Ergüden- O. Akınhay, İstanbul: Ayrıntı Yayınları.

GALBRAITH, John Kenneth (2004). İktidarın Anatomisi, çev. Ramazan Dikmen, Ankara: Hece Yayınları.

HIMMELFARB, Gertrude (select) (1949). Essays on Freedom and Power, Boston: The Beacon Press.

LAORAU, René (2001). Bilinçaltında Devlet, çev. Işık Ergüden, İstanbul: Ayrıntı Yayınları.

MARX, Karl, Engels, Friedrich (2003). Komünist Partisi Manifestosu, çev. C. Karakaya, İstanbul: Sosyal Yayınlar.

MERGUIOR, José Guilherme (1986). Foucault, çev. Nurettin Elhuseyni, İstanbul: Afa Yayınları.

PROUDHON, Pierre Joseph (1998). Mülkiyet Nedir?, çev. Vedat G. Üretürk, İstanbul: Toplumsal Dönüşüm Yayınları.

RAND, Ayn (1993). The Fountainhead, New York: New American Library.

RICHES, David (1989). Antropolojik Açıdan Şiddet, çev. D. Hattatoğlu, İstanbul: Ayrıntı Yayınları.

RUSSELL, Bertrand (2003). İktidar, çev. E. Esençay, İzmir: İlya Yayınevi. 
SENNETT, Richard (1992). Otorite. çev. K. Durand, İstanbul: Ayrıntı Yayınları.

SINCLAIR, John McHardy (2000). Collins English Dictionary, Glasgow: Harper Collins Publishers.

TORMEY, Simon (1992). Totalitarizm, çev. A. Y1lmaz-O. Akınhay, İstanbul: Ayrıntı Yayınları.

WEBER, Max (1962). Basic Concepts in Sociology, London: Peter Owen. 